\title{
DILEMA WISATA DI KOTA LHOKSEUMAWE: STUDI SOSIAL BUDAYA PADA TEMPAT WISATA WADUK JEULIKAT
}

\author{
Yanti $^{1}$, Teuku Kemal Fasya' ${ }^{1}$, Ibrahim Chalid ${ }^{1}$ \\ 1 Program Studi Antropologi, Universitas Malikussaleh Lhokseumawe \\ Aceh-Indonesia
}

\begin{abstract}
Abstrak: Tujuan penelitian ini untuk mengetahui pandangan masyarakat terhadap wisata waduk Jeulikat, untuk mempelajari dan mendeskripsikan dampak sosial ekonomi terhadap masyarakat sekitar wisata waduk Jeulikat serta untuk mengetahui konflik yang hadir di tempat wisata waduk Jeulikat. Metode pada penelitian ini adalah menggambarkan proses antropologi sosial budaya. Sumber data penelitian terdiri dari data primer dan sekunder. Teknik pengumpulan data yang digunakan adalah observasi, wawancara dan dokumentasi. Hasil penelitian menunjukkan bahwa Pandangan masyarakat terhadap wisata waduk Jeulikat sejauh ini dirasakan masih stabil, selama Pemerintah Kota Lhokseumawe mampu mengelola waduk Jeulikat sebaik mungkin, mengutamakan kepentingan umum demi masyarakat sekitar, melakukan kerjasama dan komunikasi yang baik dengan masyarakat setempat, sehingga pengembangan wisata berjalan dengan yang diharapkan. Dampak sosial ekonomi terhadap masyarakat sekitar dengan adanya wisata waduk Jeulikat pada umumnya membawa perubahan dalam membangun roda perekonomian masyarakat, membuka kesempatan lapangan kerja, berdagang atau berbisnis serta prospek yang menjanjikan terhadap Gampong Jeulikat, sehingga membantu memperlancar perekonomian masyarakat. Namun disisi lain berdampak kurang menguntungkan bagi masyarakat sekitar, hal ini dikarenakan aktivitas masyarakat terhambat karena tidak berfungsi lagi saluran irigasi sawah. Konflik yang hadir di tengah-tengah tempat wisata waduk Jeulikat yaitu adanya permasalahan dari faktor keamanan dalam hal pembebasan lahan yang terjadi antara Pemerintah Kota Lhokseumawe dengan masyarakat setempat, karena waduk yang sebelumnya dipergunakan sebagai pengairan irigasi, kini telah dijadikan sebagai tempat wisata yang handal. Selain itu juga hadir permasalahan dari faktor yang berbaur politik, dimana waduk Jeulikat yang dulunya milik masyarakat, kini telah dijadikan sebagai tempat rekreasi.
\end{abstract}

Kata Kunci: Waduk Jeulikat, Pariwisata, Perekonomian, Konflik 


\section{A. Pendahuluan}

Negara Indonesia merupakan sebuah negara kepulauan yang memiliki kekayaan alam yang luar biasa yang sangat berpotensi untuk pengembangan pariwisata dengan banyaknya potensi wisata dan potensi budaya yang dimiliki. Sumber daya alam yang dimiliki berupa hutan dengan segala isinya, daratan dengan segala bentuknya, serta lautan dengan segala potensinya yang akan dimanfaatkan secara terus-menerus untuk kepentingan pembangunan (Alfian, $2008: 17)$.

Perkembangan suatu daerah kini semakin canggih diterapkan, terutama dalam hal persaingan dunia yang semakin mengglobal, bahkan pengelolaan pembangunan yang tepat sasaran dan mampu mendukung perwujudan kapabilitas nasional, ditunjukkan dengan berkembangnya ide-ide cemerlang oleh kemampuan manusia dalam menghasilkan suatu keberhasilan yang didasarkan atas potensi sumber daya manusia.

Negara Indonesia yang sudah termasuk ke dalam era liberalisasi perekonomian global, sehingga sudah merupakan konsekuensi logis untuk mengikuti aturan main (rule of the game) perdagangan internasional yang sedang bergulir. Sehingga dalam hal ini berbagai destinasi di Indonesia saling berlomba mempersiapkan diri sedemikian rupa untuk memenuhi target kunjungan wisatawan agar dapat tercapai.

Pariwisata menurut A.J. Burkart dan S. Medlik dalam Soekadijo (2009 : 3) adalah perpindahan orang untuk sementara dan dalam jangka waktu pendek ke tujuan-tujuan di luar tempat dimana mereka biasanya hidup dan bekerja serta kegiatan-kegiatan mereka selama tinggal di tempat-tempat tujuan itu. Pariwisata merupakan salah satu industri baru yang mampu menyediakan pertumbuhan ekonomi yang cepat dalam hal kesempatan kerja, pendapatan, taraf hidup dan dalam mengaktifkan sektor produksi lain di dalam negara penerima wisatawan. Pariwisata sebagai suatu industri yang kompleks, meliputi industri-industri lain seperti industri perhotelan, industri rumah makan, industri kerajinan/cinderamata, industri perjalanan dan sebagainya.

Pembangunan pariwisata pada umumnya memberikan berbagai dampak baik dampak positif maupun dampak negatif. Dampak positif dari pembangunan 
pariwisata dapat meningkatkan pendapatan daerah, menciptakan lapangan pekerjaan serta dapat memunculkan kegiatan ekonomi di daerah dan merangsang pertumbuhan kebudayaan asli Indonesia. Namun, pembangunan tersebut juga memiliki dampak negatif dari pengembangan pariwisata yang kurang dianalisis efeknya, seperti pencemaran lingkungan, perubahan norma sosial, eksploitasi sumber daya alam secara berlebihan serta adanya perubahan keaslian kualitas keanekaragaman hayati dan ekosistem.

Berbagai macam objek dan daya tarik wisata tersebut menawarkan berbagai macam pesona yang dimiliki masing-masing objek wisata yang dapat menarik wisatawan baik wisatawan domestik maupun wisatawan mancanegara, khususnya pada objek wisata waduk Jeulikat.

Waduk Jeulikat merupakan salah satu objek wisata yang terletak di Kota Lhokseumawe yang ramai dipenuhi dengan wisatawan. Objek wisata ini merupakan salah satu pembangunan yang dikelola oleh Pemerintah Kota Lhokseumawe. Terbentang di Gampong Jeulikat Kecamatan Blang Mangat Kota Lhokseumawe, waduk Jeulikat kini menjelma menjadi salah satu objek wisata baru di kota itu. Sejak dua tahun belakangan, waduk yang terbentuk secara alami sejak puluhan tahun lalu itu sangat ramai dikunjungi oleh berbagai domestik.

Fenomena yang terjadi sekarang, banyak tempat wisata yang menimbulkan dampak positif dan negatifnya. Nilai positifnya bisa menjadi sebuah pemasukan dan pandapatan bagi daerah dan bermanfaat bagi warga sekitar yang mengelolanya. Namun dari sisi negatifnya jika tidak dijaga dan dirawat dengan baik, wisata alam tersebut menjadi rusak. Bahkan dulunya waduk tersebut berfungsi sebagai mengairi sawah hingga ke Gampong Blang Weu Panjoe tetangga Jeulikat. Waduk ini menampung air hujan kemudian dialiri ke sawah saat musim tanam padi yang merupakan lahan pribadi milik masyarakat.

Sebagai studi literatur, penulis berhasil mengidentifikasi beberapa kajian sebelumnya terkait dengan kajian pariwisata, yaitu : pertama, kajian Sara Oziliana (2016), mahasiswi Fakultas FISIP Program Studi Antropologi Universitas Malikussaleh yang melakukan penelitian dengan judul "Goa Jepang dan Daya Tarik Pariwisata Sejarah". Penelitian ini bertujuan untuk mendeskripsikan aspek kesejarahan wisata Goa Jepang dan dimensi keindahan bukit Goa Jepang di Kota 
Lhokseumawe. Penelitian ini menggunakan metode pendekatan secara deskriptif kualitatif, karena data yang diperoleh melalui hasil wawancara.

Hasil penelitian menunjukkan bahwa adanya hubungan kerjasama yang positif antara Pemerintah Kota Lhokseumawe dengan masyarakat Desa Blang Panyang terhadap pelestarian objek wisata Goa Jepang dan membawa dampak yang bagus terhadap perekonomian masyarakat serta terciptanya lapangan kerja. Daya tarik yang dilakukan oleh Pemerintah Kota Lhokseumawe bersama masyarakat dan peranan duta wisata yaitu bentuk kegiatan promosi agar banyak khalayak yang mengetahui keberadaan Goa Jepang, selain itu berbagai jenis media elektronik dipakai sebagai bentuk promosi. Pemanfaatan sumber daya agar bermanfaat secara ekonomi bagi masyarakat dilakukan dengan berbagai cara.

Selanjutnya ada Annisa Widayati (2012), mahasiswi Fakultas Ilmu Pengetahuan Budaya Program Studi Jepang Universitas Indonesia yang melakukan penelitian dengan judul "Bali Sebagai Salah Satu Destinasi Pariwisata Favorit Wisatawan Jepang". Penelitian ini bertujuan untuk memberikan gambaran tentang karakteristik wisatawan Jepang saat berwisata ke luar negeri, khususnya Bali. Selain itu juga penelitian ini bertujuan untuk memberikan gambaran tentang faktor-faktor ketertarikan wisatawan Jepang terhadap Bali sebagai destinasi pariwisata. Penelitian ini menggunakan metode pendekatan secara deskriptif kualitatif, karena data yang diperoleh melalui hasil wawancara.

Hasil penelitian tersebut ditemukan peneliti bahwa Bali merupakan salah satu destinasi pariwisata favorit wisatawan mancanegara, khususnya wisatawan Jepang. Ada beberapa faktor yang membuat wisatawan Jepang datang ke Bali. Faktor tersebut diantaranya adalah adanya perasaan nostalgia yang ditimbulkan oleh objek wisata di Bali dan adanya informasi yang cukup lengkap dan menarik mengenai pariwisata Bali bagi wisatawan Jepang.

\section{B. Metode Penelitian}

Metode penelitian ini adalah sosial kualitatif, karena data yang diperoleh dengan cara mengkaji dan menggambarkan proses antropologi sosial budaya. Studi sosial budaya adalah pendekatan antropologi yang berbasis kepada sosial budaya ekonomi masyarakat yang berada di sekitar wilayah waduk Jeulikat 
Kecamatan Blang Mangat Kota Lhokseumawe. Sumber data penelitian terdiri atas sumber data primer dan sumber data skunder. Serta teknik dalam pengumpulan data penelitian ini adalah observasi, wawancara, studi dokumensi dan kajian literatur.

\section{Kajian Teori}

\section{Antropologi Budaya}

Dalam kenyataannya antropologi mempelajari semua mahluk manusia yang pernah hidup pada semua waktu dan semua tempat yang ada di muka bumi ini. Mahluk manusia ini hanyalah satu dari sekian banyak bentuk mahluk hidup yang ada di bumi ini yang diperkirakan muncul lebih dari empat milyar tahun yang lalu. Istilah "antropologi" berasal dari bahasa Yunani asal kata "anthropos" berarti "manusia" dan "logos" berarti "ilmu", dengan demikian secara harfiah "antropologi" berarti ilmu tentang manusia. Para ahli antropologi (antropolog) sering mengemukakan bahwa antropologi merupakan studi tentang umat manusia yang berusaha menyusun generalisasi yang bermanfaat tentang manusia dan perilakunya, dan untuk memperoleh pengertian ataupun pemahaman yang lengkap tentang keanekaragaman manusia (Koentjaraningrat, 2007: 1-2). Menurut Haviland (2009 : 12) cabang antropologi budaya ini dibagi-bagi lagi menjadi tiga bagian, yakni : arkeologi, antropologi linguistik dan etnologi. Untuk memahami pekerjaan para ahli antropologi budaya, maka kita harus mengetahui tentang :

1. Hakikat kebudayaan yang menyangkut tentang konsep kebudayaan dan karakteristik-karakteristiknya.

2. Bahasa dan komunikasi, menyangkut; hakikat bahasa, bahasa dalam kerangka kebudayaan

3. Kebudayaan dan kepribadian.

Antropologi budaya mengkaji tentang praktik-praktik sosial, bentuk-bentuk ekspresif, dan penggunaan bahasa, dimana makna diciptakan dan diuji sebelum digunakan masyarakat. Istilah ini biasanya dikaitkan dengan tradisi riset dan penulisan antropologi di Amerika. Antropologi budaya juga merupakan studi tentang praktik-praktik sosial, bentuk-bentuk ekspresif dan penggunaan bahasa, 
dimana makna diciptakan dan diuji sebelum digunakan oleh masyarakat manusia (Saifuddin, 2005 : 193).

Dari beberapa pengertian tersebut, ditemukan konsep yang sesuai studi ini bahwa antropologi budaya yang dimaksud adalah ilmu yang mempelajari tentang karakteristik, perilaku dan kehidupan seseorang, dimana orang tersebut dapat dimengerti oleh orang lain dalam berinteraksi dengan masyarakat. Sehingga dalam konsep ini antropologi budaya memegang peranan yang kuat dalam menggambarkan keadaan masyarakat sebagai obyek dan waduk Jeulikat Kota Lhokseumawe sebagai lokasi penelitian.

\section{Pengertian Pariwisata}

Istilah pariwisata terlahir dari bahasa Sansekerta yang komponenkomponennya terdiri dari "Pari" yang berarti penuh, lengkap, berkeliling. "Wis (man)" yang berarti rumah, properti, kampung, komunitas dan "ata" berarti pergi terus-menerus, mengembara (roaming about) yang bila dirangkai menjadi satu kata melahirkan istilah pariwisata berarti : pergi secara lengkap meningggalkan rumah (kampung) berkeliling terus menerus dan tidak bermaksud untuk menetap di tempat yang menjadi tujuan perjalanan (Pendit, 2012 : 3).

Konsep pariwisata menurut Burkart dan Medlik dalam Pitana (2005 : 46) bahwa wisatawan memiliki empat ciri, diantaranya adalah :

a. Wisatawan adalah orang yang melakukan perjalanan dan tinggal diberbagai tempat tujuan.

b. Tempat tujuan wisatawan berbeda dari tempat tinggal dan tempat kerjanya sehari-hari, karena itu kegiatan wisatawan tidak sama dengan kegiatan penduduk yang berdiam dan bekerja di tempat tujuan wisata.

c. Wisatawan bermaksud pulang kembali dalam beberapa hari atau bulanbulanan, karena perjalanan itu bersifat sementara dan berjangka panjang.

d. Wisatawan melakukan perjalanan bukan untuk mencari tempat tinggal untuk menetap di tempat tujuan atau bekerja untuk mencari nafkah.

Menurut Cohen (2004 : 533) seorang wisatawan adalah seorang pelancong yang melakukan perjalanan atas kemauan sendiri dan untuk waktu sementara dengan harapan mendapat kenikmatan dari hal-hal baru dan perubahan yang dialami selama dalam perjalanan yang relatif lama dan tidak berulang. Menurut 
Cohen (2004 : 533), konsep pariwisata adalah sebuah konsep yang jernih, garisgaris batas antara peran wisatawan dan bukan peran wisatawan sangat kabur, dan banyak mengandung kategori antara. Ada tujuh ciri perjalanan wisata, menurut pendapatnya yang membedakan wisatawan dari orang-orang lain yang juga bepergian adalah sebagai berikut :

a. Sementara, untuk membedakan perjalanan tiada henti yang dilakukan petualang (Tramp) dan pengembara (Nomad).

b. Sukarela atau atas kemauan sendiri, untuk membedakan perjalanan yang harus dilakukan orang yang diasingkan dan pengungsi.

c. Perjalanan pulang pergi, untuk membedakan dari perjalanan satu arah yang dilakukan orang yang pindah ke negara lain (Migran).

d. Relatif lama, untuk membedakan dari perjalanan pesiar (excursion) bepergian (Tripper).

e. Tidak berulang-ulang, untuk membedakan perjalanan berkali-kali yang dilakukan orang yang memiliki rumah istirahat (Holiday house owner).

f. Tidak sebagai alat, untuk membedakan dari perjalanan sebagai cara untuk mencapai tujuan lain, seperti perjalanan dalam rangka usaha, perjalanan yang dilakukan pedagang dan orang yang berziarah.

g. Untuk sesuatu yang baru dan berubah, untuk membedakan dari perjalanan untuk tujuan-tujuan lain seperti misalnya menuntut ilmu.

h. Istilah pariwisata berhubungan erat dengan pengertian perjalanan wisata, yaitu sebagai suatu perubahan tempat tinggal seseorang diluar tempat tinggalnya karena suatu alasan untuk melakukan kegiatan yang bukan untuk menghasilkan upah.

Menurut Robinson dalam Pitana (2005 : 40), pariwisata berkembang karena adanya gerakan manusia dalam mencari sesuatu yang belum diketahuinya, menjelajahi wilayah yang baru, mencari perubahan suasana, atau untuk mendapat perjalanan baru. Dengan demikian dapat dikatakan bahwa wisata merupakan suatu perjalanan yang dilakukan oleh seseorang atau lebih dengan tujuan antara lain untuk mendapatkan kenikmatan dan memenuhi hasrat ngin mengetahui sesuatu. Dapat juga karena kepentingan yang berhubungan dengan kegiatan olahraga untuk kesehatan, konvensi, keagamaan dan keperluan usaha lainnya. 


\section{Wisatawan}

Bila diperhatikan, orang-orang yang datang berkunjung disuatu tempat atau negara, biasanya mereka disebut sebagai pengunjung (visitor) yang terdiri dari beberapa orang dengan bermacam-macam motivasi kunjungan termasuk di dalamnya adalah wisatawan, sehingga tidak semua pengunjung termasuk wisatawan. Menurut International Union of Offical Travel Organization (IOUTO) (2007 : 14) dalam Soekadijo (2009 : 32), menjelaskan bahwa pengunjung yaitu setiap orang yang datang ke suatu negara atau tempat tinggal lain dan biasanya dengan maksud apapun kecuali untuk melakukan pekerjaan yang menerima upah.

Pengertian yang sama disampaikan oleh World Tourism Organization (WTO, 2004) dalam Pitana (2005 : 18), bahwa yang dimaksud dengan pengunjung (visitor) untuk tujuan statistik merupakan setiap orang yang mengunjungi suatu negara yang bukan merupakan negaranya sendiri dengan alasan apapun juga kecuali untuk mendapatkan pekerjaan yang dibayar oleh negara yang dikunjunginya.

Dengan demikian ada dua kategori pengunjung yaitu :

1. Wisatawan (Tourist) yaitu pengunjung yang tinggal sementara sekurangkurangnya selama 24 jam di negara yang dikunjunginya dan tujuan perjalanannya dapat digolongkan kedalam klasifikasi sebagai berikut :

a. Pesiar (Leasure) untuk kepentingan rekreasi, liburan, kesehatan, studi, keagamaan dan olah raga.

b. Hubungan dagang (business), keluarga, konferensi, misi dan lain sebagainya.

2. Pelancong (Exursionist) yaitu pengunjung sementara yang tinggal di suatu negara yang dikunjungi dalam waktu kurang dari 24 jam.

Dari beberapa pengertian tersebut, dalam studi ini yang dimaksud dengan pengunjung adalah seseorang yang melakukan kunjungan pada obyek dan daya tarik wisata, dimana dalam hal ini adalah obyek dan daya tarik wisata waduk Jeulikat Kota Lhokseumawe sebagai lokasi penelitian dalam pengertian wisatawan. 


\section{Objek Wisata}

Wisata adalah kegiatan perjalanan atau sebagian dari kegiatan tersebut yang dilakukan secara sukarela serta bersifat sementara untuk menikmati obyek dan daya tarik wisata. Seorang wisatawan berkunjung ke suatu tempat/daerah/Negara karena tertarik oleh sesuatu yang menarik dan menyebabkan wisatawan berkunjung ke suatu tempat/daerah/Negara disebut daya tarik dan atraksi wisata (Mappi , 2010 : 30).

Menurut Mappi (2010 : 30-33) objek wisata dikelompokan ke dalam tiga jenis, yaitu :

a. Objek wisata alam, misalnya : laut, pantai, gunung (berapi), danau, sungai, fauna (langka), kawasan lindung, cagar alam, pemandangan alam dan lainlain.

b. Objek wisata budaya, misalnya : upacara kelahiran, tari-tari (tradisional), musik (tradisional), pakaian adat, perkawinan adat, upacara turun ke sawah, upacara panen, cagar budaya, bangunan bersejarah, peninggalan tradisional, festival budaya, kain tenun (tradisional), tekstil lokal, pertunjukan (tradisional), adat istiadat lokal, museum dan lain-lain.

c. Objek wisata buatan, misalnya : sarana dan fasilitas olahraga, permainan (layangan), hiburan (lawak atau akrobatik, sulap), ketangkasan (naik kuda), taman rekreasi, waduk, taman nasional, pusat-pusat perbelanjaan dan lainlain.

Dalam membangun obyek wisata tersebut harus memperhatikan keadaan sosial ekonomi masyarakat setempat, sosial budaya daerah setempat, nilai-nilai agama, adat istiadat, lingkungan hidup, dan obyek wisataitu sendiri. Pembangunan obyek dan daya tarik wisata dapat dilakukan oleh Pemerintah, Badan Usaha maupun Perseorangan dengan melibatkan dan bekerjasama pihak-pihak yang terkait.

Pembangunan tempat wisata memberikan berbagai dampak baik dampak positif maupun dampak negatif. Dampak positif dari pembangunan pariwisata dapat meningkatkan pendapatan daerah, menciptakan lapangan pekerjaan serta dapat memunculkan kegiatan ekonomi di daerah dan merangsang pertumbuhan kebudayaan asli Indonesia. Namun juga menimbulkan dampak negatif dari 
pengembangan pariwisata yang kurang dianalisis efeknya, seperti pencemaran lingkungan, perubahan norma sosial, eksploitasi sumber daya alam secara berlebihan serta adanya perubahan keaslian kualitas keanekaragaman hayati dan ekosistem.

Permasalahan yang terjadi dalam kepariwisataan perlu mendapatkan tanggapan dari berbagai publik. Hal-hal yang dapat dilakukan antara lain, memiliki pemikiran baru yang belum pernah dilakukan sebelumnya, menanggulangi lingkungan yang telah mengalami perubahan serta dapat mengembangkan suatu alasan yang diperlukan sebagai dasar landasan bagi pelaksanaan pengembangannya. Berdasarkan hal tersebut di atas, penulis mengangkat tempat wisata waduk Jeulikat Kecamatan Blang Mangat Kota Lhokseumawe sebagai subjek yang dilakukan dalam penelitian ini.

\section{Pembahasan}

Waduk Jeulikat merupakan salah satu objek wisata baru yang terletak di daerah Gampong Jeulikat Kecamatan Blang Mangat Kota Lhokseumawe Provinsi Aceh. Waduk tersebut terkurung di kaki perbukitan yang hijau dan lokasi ini tentunya menawarkan pemandangan alam yang mempesona, sehingga membuat pengunjung merasa betah dengan berlama-lama di tempat wisata ini untuk menikmati pemandangan dari lereng bukit sebelah timur.

Di waduk Jeulikat ini pula para pengunjung bisa menaiki wahana air seperti bebek dayung sambil menikmati panorama alam di sekitar waduk Jeulikat dengan membayar biaya sebesar Rp. 20.000 untuk bisa memanfaatkan fasilitas bebek dayung selama satu jam. Pengunjung yang ingin menyeberangi waduk bisa menaiki sebuah rakit yang dioperasikan oleh sejumlah warga Jeulikat. Rakit tersebut memuat kapasitas sejumlah sepuluh orang yang di tarik dengan mengunakan tali dari sebuah pondok di sudut kanan waduk tersambung ke seberang di sebelah selatan dengan tarif Rp. 2.000 per orang.

Tempat wisata waduk Jeulikat juga baru saja dibangun rumah panggung (rumah adat Aceh) yang masih dalam proses pembuatan, nantinya rumah panggung ini akan di isi dengan barang unik yang berasal dari Aceh. Di sebelah kanan juga sedang di bangun jembatan gantung untuk bisa menyeberangi kawasan 
area water boom. Waduk ini juga memiliki taman yang sangat indah dengan ditanami tanaman nan hijau dan bunga-bunga yang menarik seperti mawar, melati dan jenis bunga lainnya.

Untuk menempuh lokasi pada waduk Jeulikat bisa di tempuh lewat dua jalur. Pertama dari jalan lintasan Medan-Banda Aceh yaitu daerah Cunda yang masuk ke arah Cot Sabong dengan melintasi jalan aspal yang membelok Gampong Blang Poroh hingga tembus ke Gampong Lhok Mon Puteh Kecamatan Muara Dua sampai ke Gampong Jeulikat. Kedua dari arah jalan Medan-Banda Aceh masuk ke simpang jalan elak kawasan Alue Awe atau depan komplek kampus STAIN Malikussaleh, melintasi jalan elak hingga ke Jeulikat. Jika masuk melalui jalur Cot Sabong - Blang Poroh - Lhok Mon Puteh ke waduk Jeulikat hanya butuh waktu kurang lebih 10 menit. Maka jalur yang lebih dekat ke waduk ini yaitu dari jalur Cot Sabong dibandingkan lintasan simpang elak.

\section{Pandangan Masyarakat Terhadap Wisata Waduk Jeulikat}

Dalam pengembangan suatu daerah atau kawasan untuk ekowisata pada dasarnya perlu dilakukan berbagai konsep untuk mengetahui perkembangan potensi wisatanya. Umumnya wisata alam yang ditemukan di suatu daerah atau kawasan pengembangan ekowisata adalah sungai, danau, waduk, pantai, hutan, goa, air terjun. Hal ini dilakukan untuk memudahkan pengelolaan dalam mengevaluasi tempat wisata secara menyeluruh dan memperhatikan proses pengembangan dalam menarik pasar wisata.

Sesuai dengan kondisi daerah dan keindahan alamnya, kawasan waduk Jeulikat yang terletak di Kecamatan Blang Mangat ini mempunyai peluang yang baik untuk dikembangkan, karena masih banyak potensi alam yang belum dimanfaatkan secara serius dan profesional, keindahan alam dan potensi wisata yang terkandung di dalam kawasan wisata waduk ini belum semuanya tergali. Selain itu Pemerintah Kota Lhokseumawe berupaya menjadikan wisata waduk Jeulikat sebagai salah satu sektor unggulan untuk meningkatkan pendapatan asli daerah dan masyarakat.

Pengelolaan waduk yang baik tentu akan menimbulkan pandangan masyarakat dengan konsekuensi yang logis bahwa setiap kebijakan dan langkah- 
langkah harus bisa mengakomodasi berbagai aspek yang bersinggungan langsung alam sekitar, sehingga tercapainya tujuan dan sasaran yang diharapkan. Pandangan masyarakat tidak terlepas dari pada arahan, bimbingan maupun masukan dari Pemerintah Kota Lhokseumawe dalam mewujudkan tempat wisata yang handal di Kecamatan Blang Mangat Gampong Jeulikat.

Pandangan masyarakat tentang keberadaan potensi objek wisata sebenarnya tercermin dari hal pendapat, keinginan, harapan dan tanggapan masyarakat atas kegiatan pengembangan di wilayah yang mereka tempati. Pandangan masyarakat yang berinteraksi langsung dengan objek wisata waduk berkaitan erat dengan pendapat mengenai pengembangan objek wisata, pengetahuan serta keterlibatan antara Pemerintah Kota Lhokseumawe dengan masyarakat.

Mengelola suatu tempat wisata pada umumnya tidak terlepas dari pada pandangan masyarakat dalam menanggapi dilema dan problema yang terjadi di suatu daerah. Demi mencapai pengembangan objek wisata yang handal sesuai dengan keinginan yang diharapkan, maka untuk itu perlu dilakukan keterlibatan masyarakat dalam proses perencanaan dan pengembangan objek wisata baik dalam hal penyedia jasa bagi wisatawan maupun sebagai pengelola dalam menjaga kelestarian objek wisata (Ross dan Glen F, 2008 : 31). Ross dan Glen F (2008: 63) menjelaskan bahwa dalam konteks wisata, Pemerintah dan masyarakat memiliki peran yang penting dalam memanfaatkan potensi alam yang dimiliki oleh daerah ini. Objek wisata yang memiliki potensi wisata yang baik akan menjadi sarana penting dalam meningkatkan kesejateraan masyarakatnya. Untuk mewujudkan itu, pemerintah harus semaksimal mungkin mendukung pengembangan potensi alam ini. Apalagi dalam era reformasi, waduk Jeulikat telah menjadi daerah wisata baru yang diharapkan dengan potensi alam berupa pariwata dapat menjadi alasan untuk menciptakan kemakmuran yang menyeluruh bagi masyarakat di Kota Lhokseumawe ini.

\section{Dampak Sosial Ekonomi Terhadap Masyarakat Sekitar Waduk}

Sektor pariwisata merupakan salah satu sektor yang cukup memiliki potensi untuk dikembangkan di Kota Lhokseumawe dan sektor ini merupakan 
salah satu sektor yang dapat mendukung pertumbuhan suatu wilayah. Pengembangan sektor pariwisata dijadikan sebagai salah satu sektor andalan yang mampu memberikan kontribusi besar bagi peningkatan pendapatan asli daerah dan menggerakkan perekonomian daerah.

Waduk Jeulikat yang terletak di Kota Lhokseumawe merupakan salah satu tempat wisata yang memiliki daya tarik wisata dengan ciri khas wisata buatan yang mampu menarik wisatawan. Tempat wisata ini tentunya mempunyai potensi yang cukup baik yang dapat memberikan pemasukan bagi pendapatan daerah. Objek wisata tersebut menampilkan pesona alam yang luar biasa serta memberikan prospek yang cerah ke depannya, sehingga tempat wisata ini mampu menarik wisatawan baik wisatawan domestik maupun wisatawan mancanegara dan tentunya memberikan dampak terhadap sosial ekonomi masyarakat sekitar. Hal ini seperti yang diungkapkan oleh Bapak Ismail Abdullah selaku Geuchik Gampong Jeulikat yang menyatakan bahwa :

"Adanya pengembangan terhadap tempat wisata waduk Jeulikat ini memberikan kesempatan bekerja kepada masyarakat sekitar, masyarakat tidak perlu jauh-jauh untuk berjualan dalam memenuhi kebutuhan hidup sehari-hari, para masyarakat umumnya pemuda juga bisa bekerja sebagai pengelola dan menjaga keamanan lingkungan serta menjadi tukang parkir di wilayah seputaran area waduk. Pengembangan yang dilakukan tersebut sedikitnya membantu penghasilan bagi warga sekitar dan menambah pendapatan daerah" (Wawancara, 04/01/2017).

Dalam pengembangan harus menjalin hubungan yang harmonis antar sesama pihak dalam suatu wilayah memang sangatlah sulit dilakukan, namun upaya dalam menjalankan suatu program bagi setiap pemerintahan tidak terlepas dari pada pendekatan terhadap masyarakat sekitar, karena dengan menjalin kerjasama yang baik merupakan langkah awal dalam membina keakraban dan menentukan keberhasilan dalam suatu wilayah. Dari hasil observasi wawancara di atas dapat penulis gambarkan bahwa upaya yang dilakukan Pemerintah Kota Lhokseumawe dalam meningkatkan pengunjung pada objek wisata berjalan dengan maksimal serta upaya pengelola waduk dalam melakukan pendekatan dengan masyarakat dilakukan sesuai dengan harapan.

Sehingga pengembangan yang dilakukan Pemerintah Kota Lhokseumawe terhadap waduk Jeulikat merupakan suatu usaha efektif yang memberikan dampak 
sosial ekonomi budaya bagi para pengunjung dan masyarakat. Jika ditinjau dari segi kepariwisataan, terlihat bahwa upaya pengelola dalam mengembangkan tempat wisata dapat dilaksanakan menuju ke arah yang lebih baik, meskipun di sisi lain, terhambatnya aktivitas masyarakat dalam menanam padi di sawah, karena tempat wisata waduk Jeulikat berkaitan dengan lahan masyarakat sekitar waduk.

Pengembangan pariwisata merupakan suatu usaha untuk mengembangkan atau meningkatkan objek wisata untuk lebih baik dan menarik yang ditinjau dari segi tempat maupun fasilitas, sarana dan prasarana yang terdapat di dalamnya mampu menarik minat wisatawan untuk mengunjunginya. Alasan utama dalam pengembangan pariwisata pada suatu daerah tujuan wisata, baik secara lokal maupun regional atau ruang lingkup nasional pada suatu negara sangat erat kaitannya dengan pembangunan perekonomian daerah atau negara tersebut.

Dalam mengelola tempat wisata, perlu dilakukan pengembangan yang maksimal bagi masyarakat lokal maupun khusus yang menjadi pelaku wisata di kawasan objek wisata, sehingga dapat mengembangkan kawasan waduk jeulikat sesuai dengan visi ekowisata yaitu menjaga kelestarian sumberdaya alam dan budaya serta mampu mensejahterakan kehidupan masyarakat.

Masyarakat harus memiliki keyakinan bahwa pengembangan ekowisata mampu meningkatkan kesejahteraan hidup mereka dan pada akhirnya juga akan meningkatkan pendapatan daerah Kota Lhokseumawe. Peningkatan kesejahteraan masyarakat akan memotivasi partisipasi mereka dalam menjaga dan melestarikan sumber daya alam yang ada sehingga menjadi daya tarik kegiatan ekowisata. Berdasarkan hasil penelitian yang telah penulis lakukan dilapangan, diketahui bahwa sebahagian masyarakat bersedia terhadap pengelolaan dan pengembangan ekowisata waduk Jeulikat yang telah dilakukan, karena di samping penduduk Gampong Jeulikat menjadi ramai, selain itu juga dengan adanya pengembangan suatu daerah memberikan peluang yang lebih besar bagi masyarakat untuk berusaha dalam bisnis wisata serta mengurangi angka pengangguran dan kemiskinan dalam desa.

Kehadiran ekowisata dalam era pembangunan berwawasan lingkungan merupakan suatu misi dalam pengembangan kepariwisataan alternatif yang tidak 
menimbulkan dampak negatif baik terhadap lingkungan maupun sosial budaya masyarakat. Karena Pada dasarnya dalam mengembangkan pariwisata diperlukan sebuah usaha perencanaan. Perencanaan itu dimaksudkan agar pengembangan pariwisata dapat berjalan sesuai dengan apa yang telah dirumuskan dan berhasil mencapai sasaran yang dikehendaki. Pengembangan wisata jika tidak dikembangkan dapat menimbulkan masalah terhadap sosial budaya dan menurunnya perekonomian suatu daerah serta mundurnya kualitas kesenian.

\section{Konflik yang Hadir di Tempat Wisata Waduk Jeulikat}

Pariwisata merupakan salah satu sektor yang berkaitan erat dan pendekatan dengan dunia politik. Meskipun keduanya adalah dua kajian yang berbeda, namun keduanya terlepas satu sama lain. Pariwisata tidaklah berada dalam ruang hampa yang bebas dari pengaruh dinamika politik, demikian juga politik tidak bisa lepas dari dinamika pariwisata.

Pembicaraan mengenai pariwisata kini telah sampai kepada hal baik maupun buruknya citra negeri ini di mata dunia internasional. Indonesia dianggap sebagai negeri yang tidak aman, sarang teroris, gemar berdemo serta gejala politik yang sering menimbulkan konflik di berbagai daerah. Dapat dibayangkan berapa besar kerugian yang dialami, apabila hal ini dikaitkan dengan banyaknya jumlah wisatawan yang akan berkunjung pada tempat wisata dalam suatu daerah. Timbulnya konflik sosial dan kerusuhan sosial secara sporadis di beberapa daerah serta situasi dan kondisi politik yang masih memanas meskipun belum menyentuh daerah tujuan wisata akan berakibat pada kurang terjaminnya keamanan bagi para wisatawan.

Fenomena globalisasi telah membuat pergerakan ekonomi maupun politik berkembang semakin cepat. Globalisasi jika ditelisik lebih dalam, bukanlah sesuatu hal yang bebas nilai. Begitu sebaliknya dengan ekonomi poliltik pada wisata waduk jeulikat, terlihat bahwa pengaruh globalisasi memiliki kepentingan sebagai kendaraan sebuah proyek besar. Penulis melihat bahwa dalam ruang lingkup wisata waduk jeulikat terdapat konsep ekonomi yang mementingkan unsur politik di dalamnya, dimana unsur tersebut lebih dikenal dengan perspektif ekonomi politik. 
Bapak Munawir selaku Sekretaris Gampong Jeulikat menjelaskan bahwa :

"waduk ini sebenarnya sudah sejak lama didirikan, pada mulanya waduk ini dipergunakan masyarakat setempat sebagai tempat penampungan air untuk mengairi air ke sawah pada saat musim tanam padi, namun pada tahun 2014 waduk ini di beli dan dijadikan sebagai tempat wisata yang dikelola oleh Bapak Suaidi Yahya selaku Walikota Lhokseumawe. (Wawancara, 04/01/2017).

Kelemahan dari wisata waduk Jeulikat diantaranya adalah keterbatasan sumber daya masyarakat sekitar waduk, selain itu juga keterbatasan dalam pengelolaan wisata waduk tersebut. Sedangkan hambatan yang muncul dalam pengembangan objek wisata waduk Jeulikat antara lain adalah kebersamaan dalam membangun tempat wisata serta dukungan dari masyarakat yang masih minim. Hal ini disebabkan karena sebahagian lahan dari masyarakat yang dahulu dipergunakan sebagai aktivitas bertani para warga, sekarang telah dipergunakan sebagai lahan untuk perluasan waduk, akibatnya sebahagian aktivitas masyarakat terhenti karena waduk tersebut tidak berfungsi lagi sebagai saluran irigasi. Jika permasalahan ini dibiarkan berlarut-larut, maka akan berakibat fatal terhadap pengembangan waduk dan tingkat wisatawan yang berkunjung.

Pada hakikatnya, suatu Negara maupun wilayah tidak bisa berjalan sendiri. Dalam suatu wilayah demokrasi, terdapat dua entitas yang tidak dapat dipisahakan yaitu antara Pemerintah sebagai representasi dan masyarakat sebagai kelompok. Kedua unsur ini harus berjalan bersama serta saling melengkapi satu sama lain. Pemerintah membutuhkan masyarakat untuk saling bahu membahu dalam melaksanakan program-programnya. Kehadiran dan dukungan masyarakat yang kuat juga dapat menjadi alat kontrol Pemerintah agar tidak terjadi penyimpangan dari tujuan penyelenggaraan. Demikian juga masyarakat yang tidak bisa berjalan sendiri tanpa pemerintah. Terlebih pemerintah melalui mekanisme pemilihan umum (kontrak sosial) telah dipercayai sebagai wakil yang dapat mengurusi dan membantu pemenuhan hak-hak masyarakat.

Ketika pariwisata mengalami perkembangan seperti yang diharapkan oleh semua pihak, ada beberapa faktor yang perlu mendapat perhatian dan penanganan yang serius demi pengelolaan wisata, sehingga tidak menimbulkan 
permasalahan, bahkan wisata tersebut justru menjadi daya dukung yang diandalkan, karena dapat memperkaya kepariwisataan itu sendiri.

Dilema yang terjadi saat ini bahwa dalam ruang lingkup tempat wisata waduk Jeulikat terdapat konflik yang menyebabkan timbulnya permasalahan yang tidak diharapkan, baik itu terhadap pembebasan lahan, perebutan lahan maupun problema yang berbaur politik. Gampong Jeulikat merupakan daerah yang mayoritasnya bekerja sebagai petani, sebahagian masyarakat merasa khawatir dengan pengairan irigasi yang dulunya memadai dan dimanfaatkan masyarakat dalam aktivitas menanam padi di sawah, kini tidak dapat berfungsi karena waduk tersebut dipergunakan sebagai sarana tempat wisata (http://travel.kompas.com) (tanggal akses : 10/01/2017).

Dalam menarik para wisatawan yang akan berkunjung ke suatu daerah, faktor utama yang sangat berpengaruh adalah faktor keamanan, yaitu sejauh mana para wisatawan mendapatkan kenyamanan dan jaminan keamanan selama berada di tempat wisata. Sedangkan faktor kedua yaitu politik dalam negeri. Jika ingin menarik wisatawan yang ramai maka faktor kondisi dan situasi politik perlu dibenahi terlebih dahulu, agar tidak menimbulkan kebingungan pada masyarakat serta memenuhi keinginan masyarakat sekitar. Selain itu, Pemerintah Kota Lhokseumawe bersama seluruh elemen masyarakat saling bahu membahu untuk memperbaiki keadaan suatu wilayah yang semakin porak poranda. Mudahmudahan Kota Lhokseumawe aman dan tentram demi menanti datangnya secercah harapan bagi terciptanya keamanan dan situasi politik yang aman di daerah kita, sehingga seluruh lapisan masyarakat dapat mendukung bangkitnya wisata waduk Jeulikat.

\section{Kesimpulan}

Adapun kesimpulan dari hasil penelitian di atas adalah sebagai berikut :

1. Pandangan masyarakat terhadap wisata waduk Jeulikat sejauh ini dirasakan masih stabil, selama Pemerintah Kota Lhokseumawe mampu mengelola waduk Jeulikat sebaik mungkin, mengutamakan kepentingan umum demi masyarakat sekitar, melakukan kerjasama dan komunikasi 
yang baik dengan masyarakat setempat, sehingga pengembangan wisata berjalan dengan yang diharapkan.

2. Dampak sosial ekonomi terhadap masyarakat sekitar dengan adanya wisata waduk Jeulikat pada umumnya membawa perubahan dalam membangun roda perekonomian masyarakat, membuka kesempatan lapangan kerja, berdagang atau berbisnis serta prospek yang menjanjikan terhadap Gampong Jeulikat, sehingga membantu memperlancar perekonomian masyarakat. Namun disisi lain berdampak kurang menguntungkan bagi masyarakat sekitar, hal ini dikarenakan aktivitas masyarakat terhambat karena tidak berfungsi lagi saluran irigasi sawah.

3. Konflik yang hadir di tengah-tengah tempat wisata waduk Jeulikat yaitu adanya permasalahan dari faktor keamanan dalam hal pembebasan lahan yang terjadi antara Pemerintah Kota Lhokseumawe dengan masyarakat setempat, karena waduk yang sebelumnya dipergunakan sebagai pengairan irigasi, kini telah dijadikan sebagai tempat wisata yang handal. Selain itu juga hadir permasalahan dari faktor yang berbaur politik, dimana waduk Jeulikat yang dulunya milik masyarakat, kini telah dijadikan sebagai tempat rekreasi. 


\section{Daftar Pustaka}

Alfian. 2008. Persepsi Masyarakat Tentang Kebudayaan. PT Gramedia. Jakarta.

Annisa Widayati. 2012. Bali Sebagai Salah Satu Destinasi Pariwisata Favorit Wisatawan Jepang. Skripsi. Fakultas Ilmu Pengetahuan Budaya. Program Studi Jepang. Universitas Indonesia. Depok.

Departemen Kebudayaan dan Pariwisata RI. 2009. Undang-undang Republik Indonesia Nomor 10 Tentang Kepariwisataan. Indonesia. Jakarta.

Haviland, William A. 2009. Antopologi. Jilid 1. Alih Bahasa : R.G. Soekadijo. Erlangga. Jakarta.

Koentjaraningrat. 2007. Sejarah Teori Antropologi, Jilid 1. Univesitas Indonesia Press. Jakarta.

Mappi. 2010. Manajemen Kepariwisatan. PT Pradnya Paramita. Jakarta.

Moleong, Lexy, J. 2005. Metodelogi Penelitian Kualitatif. Rosdakarya. Bandung.

Mulyana, Deddy. 2006. Metode Penelitian Kualitatif (paradigma baru ilmu komunikasi dan ilmu sosial lainya). Rosdakarya. Bandung.

Pawito. 2007. Penelitian Komunikasi Kualitatif. LKIS Pelangi Aksara. Yogyakarta.

Pendit, S. Nyoman. 2012. Ilmu Kepariwisataan. Pradanya Paramita. Jakarta.

Pitana, I Gede. 2005. Sosiologi Pariwisata. Yogyakarta.

Ross, Glen F. 2008. Psikologi Jakarta. Yayasan Obor Indonesia. Jakarta.

Sara Oziliana. 2015. Goa Jepang dan Daya Tarik Pariwisata Sejarah. Skripsi. Program Studi Antropologi. Fakultas Ilmu Sosial dan Ilmu Politik. Universitas Malikussaleh. Lhokseumawe.

Saifuddin, Achmad, F. 2005. Antropologi Kontemporer : Suatu Pengantar Kritis Mengenai Paradigma, Prenada Media. Jakarta.

Soekadijo, R.G. 2009. Anatomi Pariwisata, Memahami Pariwisata Sebagai Sistemic Lingkage. Gramedia Pustaka Utama. Jakarta.

Suwantoro G. 2014. Dasar-dasar Pariwisata. PT. Gramedia Pustaka Utama. Jakarta.

Wahab, Salah. 2013. Manajemen Kepariwisataan. PT. Pradnya Paramita. Jakarta.

Yoeti, Oka A. 2006. Pengantar Ilmu Pariwisata. Angkasa. Bandung.Scott, Jacqueline, and Rosemary Crompton, and Clare Lyonette, eds. 2010.Gender 
Aceh Anthropological Journal, Vol. 4, No. 1 , hlm: 122-141, April 2020

inequalities in the 21st century: new barriers and continuing constraints. Cheltenham, England: Edward Elgar. 